This is a pre-print. It was first published on 1 July 2016. Please cite the final version published in Journal of Applied Philosophy, 35, no. 3, 2018

https://doi.org/10.1111/japp.12234

\title{
Fiduciary Duties and Moral Blackmail
}

\author{
Simon Keller, Victoria University of Wellington
}

\section{Introduction}

Suppose that you are my neighbor, I have a dog, and I am about to go on vacation. I would very much like it if you were to take care of my dog while I am away. I ask you politely, and you politely say no. So I decide to use less polite means. Consider three strategies I might employ.

First, I might tell you that if you do not look after my dog while I am away, then I will tell your husband that you are having an affair. If you do not take care of my dog for me, that is to say, then I will do something that harms you. My strategy here is to place you in a situation under which doing what I want you to do will bring you a lesser harm than the alternative. Looking after my dog is a small burden compared with the harm of having your husband told that you are having an affair. I try to make it the case that looking after my dog will best serve your interests, in the circumstances in which you are placed.

Second, I might tell you that it does not surprise me that you are not willing to take care of my dog, because you have always been too weak-minded to accept responsibility. I might add that your mother - may she rest in peace - would be terribly disappointed if she were to know that you still act as selfishly towards others as you 
always acted towards her. Now my strategy is to take advantage of your susceptibility to guilt and shame. I try to make you agree to look after my dog by manipulating your emotions. My strategy may succeed by leaving you emotionally overwhelmed, even if you still think that taking responsibility for my dog is not in your best interests.

As a third strategy, I might leave a note under your door, just as I am leaving for my vacation, in which I tell you that I have left the dog at home, I have not arranged for anyone else to take care of it, and I cannot be contacted while I am away, so if you do not take care of the dog then it will probably starve and die. My goal in pursuing this strategy is to appeal to your moral sensibility. The dog's life depends on you now, and it would be wrong of you to let an innocent dog die. My strategy need not presume that you have any emotional attachment to the dog; perhaps I know that you dislike it. And my strategy need not involve any appeal to your self-interest. If the strategy succeeds, it succeeds by placing you into a situation under which it would be morally wrong of you not to look after my dog. I try to manipulate you by making you feel morally obliged to do what I want you to do.

This third strategy exhibits the kind of manipulation that I want to explore in this paper. It gives an example of (what I will call) "moral blackmail.” To commit moral blackmail is to perform a wrongful act that forces someone to do something by making her alternatives morally unacceptable. (I will say more later about what moral blackmail is and how it works, and how it is connected to ordinary blackmail.)

I think that moral blackmail is found in many kinds of human interactions. In this paper, I want to show that one way in which a person can become vulnerable to moral blackmail is through her acting as a fiduciary within certain sorts of legal and 
professional fiduciary relationships. A fiduciary relationship can sometimes give rise to a distinctive kind of moral obligation - the kind of obligation we find within our special moral relationships - and when it does, the fiduciary can be exposed to moral blackmail. That tells us something about the moral dimensions of fiduciary arrangements, and it also helps establish a claim about moral blackmail more generally. I want to show that the notion of moral blackmail is coherent and that the phenomenon of moral blackmail is real and significant. If moral blackmail can be found within fiduciary relationships, then it can be found in other parts of life too. ${ }^{1}$

I will begin with a discussion of fiduciary duties. Then I will say a little about the moral obligations that arise within special relationships, and then about how some fiduciary relationships can naturally give rise to special moral relationships, with attendant special moral obligations. I will then look more closely at the notion of moral blackmail and say how it is like and unlike ordinary instances of blackmail. With all of that in hand, I will make the case that people who hold certain kinds of fiduciary duties can be vulnerable to moral blackmail.

\section{Fiduciary duties and the law}

The term "fiduciary duty" is used most prominently in the law. As it appears in the law, a fiduciary duty is a legal duty held by one party, the fiduciary, that has as its object a second party, the beneficiary. The fiduciary relationship is the relationship between the fiduciary and the beneficiary. One paradigm case of fiduciary duty is the duty held by a financial trustee who manages money on someone else's behalf. The trustee - the fiduciary - has the duty to manage the money in such a way as to serve the 
interests of the party on whose behalf she acts - the beneficiary; this means, among other things, that the trustee may not use the money for her own benefit. ${ }^{2}$ Many other kinds of relationship have been said to involve fiduciary duties under the law. These include relationships between a lawyer and a client, between a stockbroker and a client, between a doctor and a patient, between a parent and a child, and between a state and its Aboriginal people. ${ }^{3}$

There is controversy over the nature and scope of fiduciary law, and there are arguably differences in how fiduciary duties are construed in different jurisdictions. ${ }^{4}$ One disagreement is about whether there is anything interesting and distinctive about the category "fiduciary relationship." Some say that there is no such thing as a fiduciary relationship "as such," and instead that fiduciary relationships are always subsequent to independently established rules and principles ${ }^{5}$; others argue that the fiduciary relationship has a special character that explains and justifies the rules and principles by which the conduct of fiduciaries is bound. ${ }^{6}$ Another disagreement is over whether fiduciary duties are always established by consent, as opposed sometimes to being unchosen. ${ }^{7}$ For all the disagreement about how exactly to define and construct fiduciary relationships, however, there are some significant features that most fiduciary relationships, at least, are widely agreed to share.

A fiduciary duty is a special duty, in two respects. First, it is held to the beneficiary in particular; it is a duty that the fiduciary does not hold towards just anyone. For example, if a financial trustee has a fiduciary duty to the person whose money she manages, then she must manage this money in the beneficiary's interests, over and above the interests of anyone else, and she does not have the duty (or the right) to do the same 
for others' money. Second, the fiduciary's duty to the beneficiary is special because it places a demand on the fiduciary that is not shared by just anyone; the fiduciary holds a duty to the beneficiary that is not held by others. The financial trustee, for example, holds her fiduciary duty because she holds a particular appointment, which usually comes with payment and with special knowledge of and power over the money she manages. That is a position she holds, but other people do not, and so she has duties (and certain rights) regarding the beneficiary that are hers alone.

A fiduciary duty, characteristically, is a duty to serve the interests of the beneficiary. ${ }^{8}$ How the relevant interests are conceived, and what the fiduciary is obliged and permitted to do by way of serving them, differ with different fiduciary relationships.

Consider the difference between the fiduciary duty of a financial trustee and the fiduciary duty of a doctor. Each is required to serve her respective beneficiary's interests, but for the financial trustee, the only relevant interest (usually) is the interest in having more money. The doctor, in contrast, needs to serve the beneficiary's interest in having good health. What the doctor must focus on in doing her duty to her patient is quite different from what the financial trustee must focus on in doing her duty to the person whose money she manages.

Similarly, the restrictions and requirements to which the financial trustee is subjected in serving her beneficiary's interests are different from those that fall upon the doctor. Arguably, the major fiduciary duties held by the trustee are to make no profit from her management of the beneficiary's money and to avoid situations that would involve a conflict between the beneficiary's interests and her own. ${ }^{9}$ The doctor's fiduciary duty to her patient, in contrast, may include the duty to make decisions on the 
patient's behalf when the patient is ill-informed or incapacitated, to refuse to act as the patient asks her to act - to refuse to give him medication that in the doctor's judgment will be harmful, for example - and, plausibly, to be proactive in identifying and reporting health-related problems that the patient might not be aware of himself. ${ }^{10}$

What the financial trustee and the doctor still have in common, though, is the duty to set out to do what is best for the beneficiary - in a certain respect and within certain limits. A characteristic feature of the fiduciary relationship is that the fiduciary is bound to be oriented towards the good of the beneficiary.

Usually, furthermore, part of the reason why it makes sense to consider the fiduciary bound to serve the beneficiary's interests is that the fiduciary holds power over those interests. The fiduciary may have expertise that the beneficiary lacks, may have institutional authority over the beneficiary, or may be trusted to make decisions that the beneficiary cannot make herself. ${ }^{11}$ Characteristically - arguably always - the beneficiary is a vulnerable party in the fiduciary relationship, in at least some crucial respects. ${ }^{12}$ The beneficiary's interests depend upon the fiduciary's carrying out her role responsibly, and often the beneficiary, along indeed with society at large, must take the fiduciary's good intentions on trust. ${ }^{13}$ In dealing with your financial advisor, for example, you will allow her advice and decisions to affect your financial interests, and you need to trust that she knows more about the market than you do and that she will use her knowledge to serve your interests. When society establishes the medical profession, as another example, it places doctors in a position of privilege and power, on the understanding that doctors will use their expertise to advance the health of their patients. 
Without pretending to offer a definition of fiduciary duties, then, I want to say the following. Characteristically, a fiduciary has a special duty towards a beneficiary, and that duty is to set out to serve the beneficiary's interests, of a certain kind and in certain ways and within certain limits. And characteristically, the fiduciary holds a relevant kind of power over the beneficiary and the beneficiary is therefore vulnerable to the fiduciary's acts and decisions; the fiduciary relationship, often, is one of power and vulnerability.

\section{Fiduciary duties beyond the law}

While "fiduciary duty" is predominantly a legal term, the notion of fiduciary duty is also used in other contexts, to identify standards grounded in sources other than the law. The kind of relationship that characteristically holds between a fiduciary and a beneficiary can also be found elsewhere, and can be used to explain other sorts of duties.

Many legal fiduciary relationships hold between professionals and clients:

stockbroker and client, doctor and patient, and so on. The standards to which people are answerable in their professional roles, however, usually go well beyond the standards they must meet in order to comply with the law. Being an excellent doctor, for example, involves more than just being a doctor who does not do anything illegal. And theorists have sometimes found use for the notion of fiduciary duty in explaining the ethical standards attached to certain professions.

The good nurse, for example, is sometimes characterized as a nurse who performs well in a fiduciary role. The nurse has special training and expertise and is entrusted with care of her patient, and the patient is often in a position of being distressed, incapacitated, 
or in other ways vulnerable while in the nurse's care. Part of what it is for a nurse to do her job well, plausibly, is for her to set out to serve the patient's interests as best she can: to discharge a "fiduciary responsibility." ${ }^{14}$ Underlying this standard, and the use of the term "fiduciary," is not a body of law, in the first instance, but rather a conception of the function and calling of a nurse and of what it takes to achieve excellence as a member of the nursing profession.

The fiduciary model can be applied to many professional contexts. Often, inhabiting a professional role involves taking on a special responsibility for the interests of certain vulnerable parties, and performing well in the role involves doing a good job in meeting that responsibility. Teachers may be said to have fiduciary duties to their students, for example. ${ }^{15}$ We may even say that a personal trainer has a fiduciary duty to her client; as a personal trainer, her job is to use her special expertise to advance the health and fitness of her client, who has placed his trust in her and is prepared to follow her guidance on the understanding that doing so will serve his own best interests. Again, the point of speaking of "fiduciary" relationships here is not primarily to speak of the laws to which teachers and personal trainers - to stick with the examples - are subject, but rather to say something about what it means for the jobs of teacher and personal trainer to be done well.

The fiduciary model can also be used to postulate duties that exist outside or prior to any legal or professional standards. Evan Fox-Decent says that the authority of parents over their children emerges from the nature of parent-child relationship, which he characterizes as fiduciary relationship. ${ }^{16}$ That fiduciary relationship, on Fox-Decent's view, grounds both the moral and the proper legal duties of parents to their children; even 
in the absence of a legal regime, or in the presence of one that is utterly misguided, the parent-child relationship could then still be understood as a fiduciary relationship, and the parent could hold a strictly moral fiduciary duty to her child.

It is sometimes possible, then, to speak of fiduciary duties without meaning to fall back onto the law. The professional duties of doctors, nurses, teachers, and personal trainers - and we might add to the list therapists, personal carers, real estate agents, and more - are relevantly similar to the duties of fiduciaries under the law, and calling them "fiduciary" duties can be informative. I will restrict my use of the term to legal and professional duties, but, as noted, it is not implausible to think that it can also be informatively used to characterize some strictly moral duties.

\section{The ethics of special relationships}

I want to set the framework of fiduciary duties aside for a moment and talk directly about the morality of relationships. It is very plausible to think that what we ought to do, morally, depends partly on what relationships we share with particular others. There are things you have strong reason to do for a friend, for example, that you do not have such strong reason to do for just anyone; a friend might have a legitimate complaint if you refuse to give her a ride home from the airport, but a stranger would not. As a grown child, you have a responsibility for the welfare of your own parents that you do not have for the welfare of other people's parents. You have a distinctive set of obligations towards your spouse or romantic partner. And so on.

Special relationships with others can change our moral circumstances in several different ways. A relationship might generate a special moral duty or obligation; you 
might have the moral obligation to do all you can to ensure that your parents are looked after in their old age, without having that obligation to people generally. A relationship might generate a special moral permission; you might be permitted to make your own children go to church, though you are not permitted to make just any child go to church. Or a relationship might generate a special moral reason that falls short of a duty; you might have special reason to help your friend move house, even though you do not have a duty to help her move house. ${ }^{17}$ For the sake my argument in this paper, though, I want to focus on the ways in which special relationships generate duties or (equivalently) obligations: I will sometimes call such obligations "obligations of partiality."

Philosophers disagree over exactly how special relationships come to be ethically significant. They also disagree about how obligations of partiality relate to impartial moral obligations, like obligations to respect universal human rights and to show concern for the interests of all. ${ }^{18}$ The literature contains four main accounts.

On the first account, obligations of partiality are instances of impartial obligations. In showing special concern for those with whom we share special relationships, on this account, we discharge general moral duties. Perhaps we have a general obligation to promote overall happiness, for example, and perhaps it is a good policy, if you want to promote happiness overall, to concentrate your attention on your own nearest and dearest. ${ }^{19}$

On a second account, special obligations within special relationships are explained by the place that special relationships take within our personal projects. By committing ourselves to particular relationships, runs the idea, we come to have special 
reasons to nurture and act well within those relationships. ${ }^{20}$ This view is sometimes called "the projects view.",21

A third account, sometimes called "the relationships view," says that relationships, considered in themselves, have ethical significance; relationships are valuable in their own rights or stand in their own rights as reasons. ${ }^{22}$ The relationships view says that you should give special treatment to your friends, for example, because that is how you honor the value of friendship, or because a fact like "she is my friend" stands as a fundamental reason to give someone special treatment.

The fourth account in the literature says that we have obligations of partiality towards certain individuals as a direct response to the value of those individuals. The idea is that a person has value, and the right way to respond to her value, once you are fully exposed to it, is to grant her a special place in your life for her own sake, not to compare her value with the value of others. ${ }^{23}$ As a friend, you might respond to your friend's needs and interests directly, because your friend matters in her own right, rather than deciding what to do for your friend by weighing her needs and interests against the needs and interests of every other individual. This is sometimes called "the individuals view."

While there are significant disagreements between these four accounts, I want to emphasize two points on which they - along with common sense - agree.

First, by entering certain relationships, you can come to have moral obligations that you did not have previously. The paradigmatic cases are relationships between friends, family members, and romantic partners, but there are other kinds of special relationship too. 
Second, the special obligations that emerge from special relationships are not always obligations that we hold willingly or take on knowingly. Often we simply find ourselves within special relationships, and simply find ourselves to hold the attendant special obligations. To give a few examples: you do not get to choose your parents or your siblings; you cannot always decide whom to love; you cannot always end a friendship at will; you cannot decide in advance what level of knowledge you will have about particular people, or whether they will care about you and whether you will care about them; it is not always your choice to whom you will be vulnerable, or whose interests will depend most heavily on your decisions. Even the projects view, which says that our obligations of partiality depend upon our own commitments, does not entail (and for plausibility's sake should not say) that those commitments are always subject to our own control. Without having made an active conscious decision, we can find ourselves with concerns and projects that incorporate particular relationships and particular other people, just as we can find ourselves to have entered a valuable relationship, to be exposed to another individual's self-standing value, or to have entered whatever circumstance it is that leaves us with special obligations of partiality.

\section{From fiduciary obligations to obligations of partiality}

In the discussion so far, I have looked at two kinds of special obligation: fiduciary obligations and moral obligations of partiality. To put it another way, I have looked at two kinds of normative relationship: the fiduciary relationship, which is grounded usually (though arguably not always) in the law or in a professional arrangement; and the 
relationship that holds between people who have special moral obligations to each other, like friends and family members.

Compared to special moral relationships, fiduciary relationships are usually relatively well codified and circumscribed. The fiduciary duty of a financial trustee or a doctor, for example, is much more precisely specified, and more clearly kept within certain limits, than is the moral duty of a parent. But sometimes, I want to argue, a fiduciary relationship is transformed into a special moral relationship, generating moral obligations that go beyond the obligations that the initial strictly fiduciary relationship involves.

Many fiduciary relationships cannot be converted into special moral relationships. Often a fiduciary relationship is barely a relationship at all, and has none of the features that would allow it to look at all like a special moral relationship. A trustee may have a fiduciary duty regarding certain money or property, while having no idea whose money or property it is. As James Edelman notes, you can have a fiduciary duty to a beneficiary who has not yet been born. ${ }^{24}$ In a case like this, the fiduciary relationship is purely transactional and unlikely to require anything of the fiduciary beyond the performance of a single well-specified task.

In other cases, a fiduciary may have a special duty to prevent a fiduciary relationship from extending beyond strict legal or professional bounds, even if there are natural temptations to take it in that direction. Consider the relationship between a therapist and a client. The relationship can plausibly be construed as a fiduciary relationship; the therapist is bound by the standards of his profession to use his expertise to advance the interests of the client. Given the nature of the therapist-client relationship, 
especially if it lasts over an extended period, the therapist may come to know the client well and to feel special affection for her. But in order to conduct himself as a good therapist - plausibly - he may be bound to avoid forming any additional relationship with the client and to avoid any interactions that take him outside the professional setting. As a good therapist, he might decline to meet his client for coffee, decline to give her a ride home (even if doing so would be very convenient), and resist temptations to become friends with his client. The same may be true in other cases. Sometimes the nature of a fiduciary relationship is such as to leave the fiduciary with a positive duty not to allow any further special moral relationship to develop.

But there are other kinds of fiduciary relationship. There are relationships that can develop naturally and unobjectionably into relationships of a distinctly moral character. In acting as a fiduciary, you need to serve your beneficiary's interests, of a specified kind. To know what is in her interests and to serve those interests effectively, you may need to gain special knowledge of your beneficiary, to win her trust, to understand her particular goals and challenges, and to know about her background and her values. You may need to know more about her, in some respects, than she knows herself, and you may need to accrue the authority to act against her wishes for the sake of her own interests. You may have special power over her and she may be especially vulnerable to your decisions. All of these are characteristics of a fiduciary relationship that mirror the morally powerful characteristics of special moral relationships. They make fiduciary relationships similar, in some crucial respects, to relationships between friends and family members.

One consequence is that it can be natural and predictable that a fiduciary and a beneficiary will become friends, and that the obligations that exist between them will 
come to include the duties of friendship, not just the duties that characterize their legal or professional relationship. Another consequence is that even if the fiduciary and beneficiary do not become friends - and do not become romantic partners or form any other paradigmatic kind of special personal relationship - the fiduciary may justifiably feel that she has special obligations to the beneficiary, even where fulfilling those obligations takes her outside the bounds of the fiduciary relationship.

Suppose that you are a doctor and have been dealing over time with a particular patient. In dealing with the patient's health needs, you have come to know him well and to understand his circumstances and the challenges he faces in life. You have asked him to go and visit a specialist at the hospital. On your day off, you happen to meet the patient while you are out doing your grocery shopping. He has missed a bus and is in danger of missing his appointment at the hospital. You could drive him to the appointment. It would be a little inconvenient, but you know that he will not be able to get there any other way. In such a circumstance, you may well feel that you ought to drive him to the appointment: not because you are his doctor, exactly, but rather because he is a human you know well whose crucial interests depend on what you do next. You may feel tied to him morally. You have come to share this relationship with him as a result of your being his doctor, but the obligation you now feel is not the professional or legal obligation of a doctor. It has become personal.

Now suppose that you are a nurse, and a patient you know well makes a request. She would like you to take some time to explain her health condition to her partner, and in particular to help her partner come to see that her health condition is real and not invented. You may well feel that this is not part of your job; this is not what you signed 
up for when you became a nurse. But you may also feel that you really should talk to your patient's partner, for the sake of your patient; you may know that the partner's skepticism is causing genuine distress to your patient and that you are the one person who is in a position to help. You may feel an obligation to your patient that goes beyond your obligation as a nurse.

Suppose that you resign from your job as a teacher. Some months later, one of your former students, with whom you worked closely and whom you came to know well, contacts you and asks if you could meet him to talk about his career plans. Suppose that you do not especially like the student and you have no enthusiasm for the prospect of sitting through a conversation with him, but you know that he is genuinely in need of guidance and that he is unlikely to get it from anyone else. You may justifiably judge that you no longer have any professional duty to talk to the student about his career plans, but also that, given the circumstances, it would be pretty lousy of you to turn him down. You may feel that your moral relationship with the student is such that you would be acting wrongly if you were to decide not to help him, even though helping him is no longer your job.

Suppose - finally - that you are a lawyer and you have been working very closely with a needy client. Then your boss decides to reorganize the assignments within your firm, and tells you to pass this client off to lawyers in a different division, where you know that she will get less attention and worse service. While accepting that your boss has every right to make the reassignment, and while believing that you would be doing your job perfectly well if you just accepted the reassignment and left your client to others, you may feel that if you stop working with your client now, then you will let her down. 
You may think that your boss is asking you to do your client a wrong. You may understandably feel an obligation to keep in touch with your client, to do your best to ensure that she is looked after by her new lawyers, and to put some of your free time towards helping her, if that is what she needs. You may sensibly feel that you owe her more than simply to meet the standards of your profession and the conditions of your employment.

It is fairly obvious, I suppose, that we often form special relationships as a result of our professional and legal interactions with others. Such interactions are part of life, and it is in life that we make friends and meet romantic partners. What my examples are supposed to show, however, is that there is a tendency for certain sorts of fiduciary relationships - including as they do an orientation to the beneficiary's interests, special power over the beneficiary, and so on - naturally and predictably to lead to circumstances under which the fiduciary has a special moral relationship with the beneficiary: one that generates special obligations of partiality.

The special moral obligations that arise when fiduciary relationships generate moral relationships can go beyond the original fiduciary obligations in at least two ways. They can require acts that the fiduciary obligations do not require, as in the cases of the doctor giving the patient a ride to the hospital and the nurse speaking to the patient's partner about her condition. And they can outlast the fiduciary obligations, as in the cases of the former teacher giving guidance to a former student and the lawyer continuing to look out for a client who has been reassigned. What you are required to do as a fiduciary may sometimes get you into a relationship that leads you to be required to do other things 
- required not as a fiduciary, exactly, but instead as a person who shares a morally significant relationship with another.

\section{Moral blackmail}

Consider some paradigmatic cases of blackmail. I might come across some embarrassing information about you and threaten to make it public unless you give me some money. Or I might discover that you are engaging in an illegal activity and threaten to go to the authorities unless you buy my silence. These are the sorts of acts that could get me charged with blackmail under the law. There are two points about paradigmatic cases of blackmail that I want to emphasize for the purposes of my argument in this paper. (To be clear: I am trying to use paradigmatic cases of blackmail to make my own argument clearer; I do not pretend to say anything new about blackmail itself.)

The first point is that the threats I make in subjecting you to blackmail are wrongful threats. They are threats that I am not entitled to make. Blackmail is by definition a wrongful kind of manipulation, involving action that is unfair, unwarranted, or exploitative. ${ }^{25}$ That is why I can commit blackmail when I threaten you in the paradigmatic cases, and why a retailer, for example, does not commit blackmail when she says that she will not give you the goods you want unless you pay.

The second point is that the strategy of manipulation I pursue in committing blackmail involves putting you into circumstances under which your best option is to do what I want you to do. In the paradigmatic cases, I want your money, so I try to place you into a situation under which giving me the money is better, from your point of view, than the alternatives: better to pay me off than to have the embarrassing information released 
or to have the authorities learn about your illegal activities. As a blackmailer, my basic strategy is make you do what I want you to do by making the alternatives unacceptable.

At the beginning of this paper, I mentioned some strategies by which I might try to manipulate you into taking care of my dog while I am on vacation. I could threaten to tell your husband that you are having an affair, I could appeal to your insecurity about your ability to take responsibility and your feelings of guilt regarding your deceased mother, or I could leave a note informing you that the dog's fate is in your hands. None of these strategies counts as blackmail, in its paradigmatic form, but each exhibits the two features of blackmail that I have emphasized. They each (I think you will agree) involve a wrongful, exploitative kind of manipulation, and they each attempt to make the alternatives to looking after my dog appear, for you, unacceptable.

When I threaten to tell your husband that you are having an affair, my act is very much like the act of a paradigmatic blackmailer. I do not try to get your money and I do not threaten to reveal information publicly or to the authorities, but I have something I want and I try to get it by threatening to do you a harm. As we might put it, I try to make your alternatives prudentially unacceptable.

When I try to manipulate your feelings of guilt and shame, I focus not directly on your interests but instead on your emotional situation. I try to place you in circumstances under which you are emotionally incapable of turning down my demand that you look after my dog. For what it is worth, my strategy here is like the strategies that psychotherapists sometimes label "emotional blackmail." To commit emotional blackmail is to exert power over another person by controlling his feelings of fear, guilt, or obligation. ${ }^{26}$ 
Then there is my strategy of skipping town and leaving the note. This is an instance of (what I am calling) moral blackmail. I mistreat you by placing you in a difficult moral predicament, with the life of an innocent dog depending on your actions. If my strategy succeeds, then it succeeds by making it the case that if you are to avoid doing something wrong, then you will need to do what I want you to do. I try to make you look after my dog by making the alternatives morally unacceptable. To commit moral blackmail is to perform a wrongful act that makes a person do something by making her alternatives morally unacceptable. ${ }^{27}$

There is something uncomfortable about the notion of moral blackmail, and from one point of view the idea can seem paradoxical. When I commit moral blackmail, I do something wrong, which makes it wrong for you to fail to do what I want you to do. It is as though morality rewards me for my wrongful treatment of you. As a result of your being badly treated by me, you find yourself with extra restrictions on your conduct and extra moral pressure to give me something I want. Can morality, we might ask, really work like that?

The sad answer is that it can. Our circumstances determine what morality requires of us and our circumstances are not fully within our own control. When you become someone's friend, you can never be sure what your friendship with this person will require; when you become a parent, you can never be sure exactly what sacrifices you will be required to make for this child; when you go out for a walk, you never know what circumstances you may encounter and what moral demands those circumstances may place upon you. As a result, if I have the power to change your circumstances, then I may have the power to change the moral demands you face. I may use that power wrongly; I 
may use it exploitatively or selfishly or unfairly. But still, it is a moral power, and when I use it, I may make genuine changes to your moral predicament.

If I head off for my vacation, leaving a note to say that I have left my dog behind and you are the only one who can look after it, then you may justly feel like a victim. You can justly complain that I have left you with a moral obligation - an obligation to care for an innocent dog - that you ought not to have. But the fact that you have a legitimate complaint about being left with the obligation does not imply that you do not really have it. You can have a moral obligation even when, morally, you ought not to have that obligation; you can have a genuine moral obligation because you have been treated wrongly. That is how moral blackmail becomes possible.

I have presented the moral blackmailer as someone who takes advantage of facts about the victim's moral situation, but it might be more accurate to say that the moral blackmailer takes advantage of the victim's moral sensibility, including her moral beliefs and her moral motivation. When I make you do something by making the alternatives morally unacceptable, what really matters is that I put you into a position under which you believe that your alternatives are morally unacceptable and you are motivated to avoid acts that you believe to be morally unacceptable. If you do not believe that letting my dog starve would be wrong, or if you believe it would be wrong but do not care, then my attempt to influence your behavior will fail.

An analogous point holds for ordinary blackmail. When I threaten to release the embarrassing information unless you pay, whether I get my money depends on how the incentives appear to you. If you believe that you will be better off if you keep your money - even if that belief is wrong - or if you believe that you will be worse off if you 
keep your money but you would rather keep it anyway, then I will not get what I want. Moral blackmail works by way of the victim's moral sensibility, just as ordinary blackmail works by way of the victim's conception of her own best interests.

\section{Blackmailing a fiduciary}

I have argued that some fiduciary relationships can naturally and predictably give rise to special moral relationships, and that the obligations of partiality that exist within those moral relationships can go beyond the legal or professional obligations present in the original fiduciary relationships. It follows that one way in which a person may come to have new moral obligations is by taking on a role as a fiduciary within a legal or professional relationship, which is then transformed into a special moral relationship.

Whether your role as a fiduciary leads you into a special moral relationship, and what obligations of partiality that moral relationship produces, depend on what circumstances you face. What circumstances you face will not always be under your control and may be under the control of others. To the extent to which someone else is able to influence the relevant aspects of your circumstances, he will be able to influence the facts about what special obligations you have within your special moral relationship. That leaves you vulnerable to moral blackmail.

One person who might subject you to moral blackmail, in your role as a fiduciary, is your beneficiary. As a variant of an earlier example, suppose that you are a doctor and I am your patient, and you have come to know me well and to understand my circumstances and challenges. You have asked me to see a specialist at the hospital, and I would very much like it if you would drive me to my appointment. I know that you will 
be on your day off and I know that you are likely to be out doing your grocery shopping and to have a little time on your hands. So I deliberately miss my bus and present myself to you; I explain the situation and ask you to drive me to the hospital. We may both know that you have no legal or professional obligation to meet my request. It may even be common knowledge between us that I have deliberately manipulated your circumstances. But for all that, my manipulations may succeed. You may feel that considering the relationship that has built up between us, it would be wrong for you to cause me to miss my appointment just for the sake of your own convenience. You cannot regard me simply as a patient, with whom you deal only when you are at work, and you cannot regard me simply as a stranger; you must regard me as someone with whom you share a special moral relationship. I subject you to moral blackmail by taking advantage of your moral predicament - a predicament to which you have been led as a result of your having taken on obligations, as a doctor, to further my best interests.

Now consider cases in which a third party is able to manipulate your moral relationship with a beneficiary. As a first case, imagine that you are a lawyer, with longstanding relationships with certain of your clients, and I run the law firm for which you work. I would like to make more money by bringing in additional clients, but I do not want to increase my costs. So I come up with a plan. I direct you to reduce the amount of time you spend on your present clients so as to free up time to devote to new clients. There is a risk here; if you give less attention to your present clients then they might take their business elsewhere. I know, however, that you have long-term relationships with your present clients; they rely on you and you care about them. So it is very likely, I figure, that you will respond to my request by working longer hours, ensuring that you 
continue to give your present clients the service you feel you owe them. That way, I think, I can increase your workload without having to increase your pay and without losing clients for the firm. If my strategy succeeds, then it succeeds by leaving you with a sense of moral obligation that leads you to continue to provide good service to your present clients - to do what I want you to do - even though doing so takes you beyond your professional obligations, and beyond the conditions set by your employment arrangement with me.

Imagine now that I am a government official in charge of teachers' employment. I have negotiated with teachers to set their salaries and working conditions. I would like to make a change to the arrangement, but I am pretty sure that if I do, then the teachers will resist. The teachers' greatest weapon in resisting unfavorable changes to their salaries and working conditions is to go on strike, and that would cause me considerable trouble. So I strategize, and I resolve to announce the changes in the weeks before students take their final exams and graduate, trying to ensure that a teachers' strike in response to my announcement will cause the greatest possible damage to students. The teachers have the right to strike, but their sense of obligation to their students, I figure, will make it very difficult for them to exercise that right. And if they do go on strike, then in the publicity war that follows I will have some extra ammunition. I will be able to make the teachers look heartless and selfish for abandoning their students at their time of greatest need. My goal here is to subject teachers to moral blackmail. I aim to exploit teachers' moral relationships with their students so as to gain an advantage in the professional relationship they share with me. 
These cases of moral blackmail are stylized, but in their essentials they are not unrealistic. Doctors, nurses, lawyers, trustees, and other fiduciaries can sometimes find themselves vulnerable to exploitation by their beneficiaries, and by third parties, because they are not morally able to keep their activities strictly within legal or professional contexts. It really is more difficult to go on strike if you are a nurse or a teacher than if you are a policy analyst or a software developer. The stakes are higher, because there are special personal relationships in play.

Those are just a few examples. Speaking generally, when your legal or professional obligations give you responsibility for the care of particular beneficiaries, your relationships with those beneficiaries can take on a moral dimension that goes beyond the bounds of the original fiduciary relationship, and that can leave you vulnerable to moral blackmail.

\section{Conclusion}

Moral blackmail is a real presence within human interactions. One way in which you can mistreat someone is by wrongly placing her into a position under which she is morally required to do something you want her to do. Such mistreatment is sometimes possible, and really does sometimes occur, when a person takes on certain sorts of fiduciary responsibilities within professional or legal relationships, which then generate moral relationships and new obligations of partiality, through changes in circumstances that are partly under the control of others.

The arguments of the paper are meant to identify a phenomenon that many of us need to deal with in various parts of our lives. Once moral blackmail is seen for what it is, 
we are better able to see how certain social dynamics work, and hopefully to start to see what we should do about them. Let me close with a few thoughts about some practical applications of the idea of moral blackmail, further to those I have already discussed.

The acknowledgement that moral blackmail exists makes sensible a kind of complaint that might otherwise seem confused. Sometimes when you are the victim of injustice, you can identify it as a distinctively moral kind of injustice: mistreatment through the manipulation of your moral situation. Your complaint can take the form, "I see that it is my moral obligation to perform this act, but it is morally wrong that I have this moral obligation." That can sound like a self-defeating compliant, but sometimes it is perfectly legitimate.

People who take on relatively demanding duties of care, especially people who work in the caring professions, sometimes take on a moral burden that does not fall upon others: the burden of being vulnerable to moral blackmail. Someone who takes on certain sorts of fiduciary obligations can find it more difficult to keep her professional and legal obligations separated from her personal life; she can find it more difficult, morally, to keep control over her time and energy, and to bargain for better conditions at work, among other things. It would not be unreasonable for someone who takes on relevant sorts of fiduciary obligations to expect greater pay or improved conditions, as compensation for the moral burden that comes with her role.

It is probably not a coincidence that the people most vulnerable to the kinds of moral blackmail I have discussed here are people who work in caring roles, and that people who work in such roles are often poorly paid and are more likely to be women than men. Responsibilities for caring for the neediest members of society are traditionally 
placed disproportionately on women, and one of the reasons why this allocation of responsibilities is unjust is that it leaves women more likely to stand in demanding moral relationships. There are many good things about sharing special moral relationships with others. But there are bad things too, and the bad things can become instruments of systemic injustice. When you have special moral obligations within demanding moral relationships, you have less moral freedom, and you can become a target for moral blackmail. You can be exposed to a distinctively moral form of wrongful manipulation. ${ }^{28}$

\section{NOTES}

${ }^{1}$ In Simon Keller, 'Moral Blackmail and the Family', Journal of Moral Philosophy, Forthcoming, I argue that moral blackmail is a common and powerful presence in family relationships..

${ }^{2}$ P. D. Finn, Fiduciary Obligations (Sydney: The Law Book Company, 1977), p. 4.

${ }^{3}$ See the lists in Andrew S. Gold and Paul B. Miller, 'Introduction' in Andrew S. Gold and Paul B. Miller (eds.) Philosophical Foundations of Fiduciary Law (Oxford: Oxford University Press, 2014), pp. 1-17 (see p. 1); and James Edelman, 'The Role of Justice in the Law of Obligations' in Andrew S. Gold and Paul B. Miller (eds.) Philosophical Foundations of Fiduciary Law (Oxford: Oxford University Press, 2014), pp. 21-38 (see p. 36).

${ }^{4}$ On differences across jurisdictions, see Edelman op. cit., pp. 23-34.

${ }^{5}$ Finn op. cit., pp. 1-3. 
${ }^{6}$ Paul B. Miller, 'The Fiduciary Relationship' in Andrew S. Gold and Paul B. Miller (eds.) Philosophical Foundations of Fiduciary Law (Oxford: Oxford University Press, 2014), pp. 63-90.

${ }^{7}$ See Edelman op. cit.; and Joshua Getzler, 'Ascribing and Limiting Fiduciary Obligations: Understanding the Operation of Consent' in Andrew S. Gold and Paul B. Miller (eds.) Philosophical Foundations of Fiduciary Law (Oxford: Oxford University Press, 2014), pp. 39-62.

${ }^{8}$ Finn op. cit., pp. 3, 15; and Gold and Miller op. cit., p. 10.

${ }^{9}$ Getzler op. cit., pp. 41-42.

${ }^{10}$ Miller says that a doctor becomes a fiduciary when she is authorized to act on the patient as directed by her independent judgment about what is best for patient - as opposed simply to giving the patient information that he may use as he chooses (Miller op. cit., p. 84).

${ }^{11}$ See the detailed account in Tamar Frankel, Fiduciary Law (Oxford: Oxford University Press, 2011), ch. 1.

${ }^{12}$ Miller op. cit., especially p. 73.

${ }^{13}$ Frankel op. cit., pp. 4-12.

${ }^{14}$ The fiduciary responsibility of nurses is a recurring theme in Ian E. Thompson, Kath M. Melia, and Kenneth M. Boyd, Nursing Ethics $3^{\text {rd }}$ ed. (New York: Churchill Livingstone, 1994).

${ }^{15}$ Maura Sellars, Reflective Practice for Teachers (London: Sage Publications, 2014), p. 33. 
${ }^{16}$ Evan Fox-Decent, 'Fiduciary Authority and the Service Conception' in Andrew S.

Gold and Paul B. Miller (eds.) Philosophical Foundations of Fiduciary Law (Oxford:

Oxford University Press, 2014), pp. 363-387 (see pp. 374-378).

${ }^{17}$ Simon Keller, Partiality (Princeton: Princeton University Press, 2013), pp. 2-4.

${ }^{18}$ Keller 2013 op. cit., ch. 1.

${ }^{19}$ See, for example, Frank Jackson, 'Decision-Theoretic Consequentialism and the Nearest and Dearest Objection', Ethics, 101, 3 (1991): 461-482.

${ }^{20}$ See, for example, Bernard Williams, Moral Luck (Cambridge: Cambridge University Press, 1981), pp. 1-19; and Sarah Stroud, 'Permissible Partiality, Projects, and Plural Agency' in Brian Feltham and John Cottingham (eds.) Partiality and Impartiality

(Oxford: Oxford University Press, 2010), pp. 131-149.

${ }^{21}$ Keller 2013 op. cit., ch. 2.

${ }^{22}$ See, for example, Samuel Scheffler, Boundaries and Allegiances (Oxford: Oxford University Press, 2001), especially ch. 6; and Diane Jeske, Rationality and Moral Theory (New York: Routledge, 2008), especially chh. 2-4 and p. 63.

${ }^{23}$ See, for example, Lawrence A. Blum, Moral Perception and Particularity (Cambridge: Cambridge University Press, 1994), ch. 2; J. David Velleman, 'Love as a Moral Emotion', Ethics, 109, 2 (1999): 338-374; and Keller 2013 op. cit., chh. 4-5.

${ }^{24}$ Edelman op. cit., p. 25.

25 This is part of common legal definitions of blackmail. In the United Kingdom, the crime of blackmail is defined in section 21 of the Theft Act 1968. It begins: "A person is guilty of blackmail if, with a view to gain for himself or another or with intent to cause loss to another, he makes any unwarranted demand with menaces" (my emphasis). The 
Legal Information Institute defines blackmail as "coercion by unjustifiably threatening to reveal to another person or to the public substantially true information that is embarrassing, injurious, or incriminating” (my emphasis). Legal Information Institute, 'Blackmail,' University of Cornell Law School, URL:

https://www.law.cornell.edu/wex/blackmail. Accessed 15 March 2016.

${ }^{26}$ Susan Forward, Emotional Blackmail (New York: HarperCollins, 1997).

${ }^{27}$ McConnell uses the term "moral blackmail" to describe a narrower phenomenon than the one I explore here. See Terrence C. McConnell, 'Moral Blackmail', Ethics, 91, 4 (1981): 544-567. For McConnell, moral blackmail involves an agent threatening to do some evil thing unless a second agent does some less evil thing (pp. 554-555). In McConnell's cases, as in mine, the blackmailer tries to make his victim do something by making her alternatives morally unacceptable; all of McConnell's cases fit within my conception of moral blackmail. Most of my cases of moral blackmail, however, do not fit within McConnell's conception; I do not require that the blackmailer threatens to do something evil, and I do not require that the act the blackmailer wants his victim to perform is morally wrongful.

${ }^{28}$ I am grateful for helpful comments from Samantha Brennan, Ramon Das, Nicky Drake, Robert Goodin, Charles Jones, Don Locke, Alice MacLachlan, Carolyn McLeod, Justin Sytsma, and two anonymous referees. 